\title{
Development and Evaluation of Appropriate Concepts for Sewage Disposal and Treatment in a Rural Area, Central Java, Indonesia on the Example of the Village Pucanganom
}

\author{
S. Fach*, M. Kaiser and S. Fuchs \\ University Karlsruhe, Institute for Water and River Basin Management, Kaiserstr. 12, D 76131 Karlsruhe, Germany
}

\begin{abstract}
In the province of Yogyakarta in Java, the district of Gunung Kidul is considered to be one of the poorest areas in Indonesia. Here, water shortages greatly affect the population, especially during the dry season, which lasts from April to October. Sanitation Systems in Gunung Kidul consist, either pit latrines or pour flush toilets. Without any treatment the liquid phase infiltrates in to the ground and the septic tanks are hardly ever emptied, thus posing an evident contamination potential to groundwater. So, the current situation about waste water and its treatment is inadequate. Due to this reason within the Integrated Water Resources Management Indonesia Project (IWRM) a so called pilot village Pucanganom was selected to develop an appropriate waste water treatment system considering basis conditions and resultant indicators which were weighted by the Analytical Hierarchy Process Method (AHP). The following paper will describe the application of the method to find an adaptable sanitary system for a village in Gunung Kidul, Indonesia.
\end{abstract}

Keywords: AHP Method; Conditions; Concept; Evaluation; Indicator; Waste water treatment

\section{Introduction}

In the province of Yogyakarta in Java, the district of Gunung Kidul is considered to be one of the poorest areas in Indonesia. Here, water shortages greatly affect the population, especially during the dry season, which lasts from April to October. Due to the karstic underground, rainfall rapidly seeps into the ground without sufficient surface storage. Because of the problems outlined above, an Integrated Water Resources Management (IWRM) was established in the district of Gunung Kidul. The aim of the IWRM-Indonesia project was to develop adaptable and sustainable technologies for the supply of the population in the project area with water in sufficient quantity and quality. Here, the sub-project 9 focuses on development and implementation of adapted sanitation technologies in the rural area. For that reason, an initiative which subsequently began was aimed to combine the existing competences in one place. This creates a pool of knowledge and exchange, which allows a comprehensive and integrated implementation with a high visibility and transferability to reach further rural areas. On the basis of a comprehensive set of criteria a pilot village called Pucanganom was selected which is situated in the catchment and supply area of Goa Bribin $^{1}$ and is directly connected by a sinkhole with the karstic aquifer. At this stage, waste and sewage directly reaches the water resource which enforces an urgent risk situation because of the contamination of the groundwater. The focus of the work is the implementation of an appropriate sewage and water treatment technology. In the following the initially focus is on the development and evaluation on a concept for sewage disposal and treatment which is limited in accordance to inherent local conditions.

Pucanganom was selected on the basis of several criteria as a pilot village in the area of IWRM. These criteria not only used as criteria they also show the existing problems in the village like water shortage, polluted drinking water, no waste water treatment, sinkhole right next

${ }^{1}$ Bribin Cave - underground river system to the settlement, no waste management, poor infrastructure, densely populated and increasing population.

Especially the poor infrastructure leads to the conclusion that the village is very isolated and the accessibility may prove to be a complication. Further, Pucanganom is characterized by a geographical vulnerability which is caused by the sinkhole. Opposite the general migration impulse in rural areas Pucanganom recorded a growth in the population with well-motivated inhabitants who were characterized by a good neighbourhood support. These features in the IWRM-joint project show boundary conditions and accepted as a challenge for the full implementation of the IWRM approach in the pilot village.

\section{Methodology}

As a part of the on-site data collection in Pucanganom, the water and waste water situation in the karst area was evaluated. The data collection in the village served to collect information about the water and waste water situation in the karst area and to identify the variable and fixed conditions. This evaluation resulted in indicators which determined the most applicable design for an ideal concept. Initially, a preselection of three concepts was established. With the help of these indicators, the concepts were rated and the optimized concept for the region Pucanganom was determined.

*Corresponding author: S. Fach, University Karlsruhe, Institute for Water and River Basin Management, Kaiserstr. 12, D 76131 Karlsruhe, Germany, E-mail: susanne.fach@kit.edu

Received November 20, 2011; Accepted February 02, 2012; Published February 06, 2012

Citation: Fach S, Kaiser M, Fuchs S (2012) Development and Evaluation of Appropriate Concepts for Sewage Disposal and Treatment in a Rural Area, Central Java, Indonesia on the Example of the Village Pucanganom. Hydrol Current Res S1:002. doi:10.4172/2157-7587.S1-002

Copyright: (c) 2012 Fach S, et al. This is an open-access article distributed under the terms of the Creative Commons Attribution License, which permits unrestricted use, distribution, and reproduction in any medium, provided the original author and source are credited. 
Citation: Fach S, Kaiser M, Fuchs S (2012) Development and Evaluation of Appropriate Concepts for Sewage Disposal and Treatment in a Rural Area, Central Java, Indonesia on the Example of the Village Pucanganom. Hydrol Current Res S1:002. doi:10.4172/2157-7587.S1-002

Page 2 of 5

\section{Data collection}

For the data collection, a survey in individual households was performed. There are different options and strategies. The survey was on a random basis in which a part of the population was interviewed. The selection of the elements of a total population can be made randomly or intentionally [1]. For the data collection, a random choice and, as an inspection requirement, a standard random was selected. Here, the decision on the inclusion of an element of the population into the sample was initially situated by an uncontrolled selection plan only at the discretion of the selector. Furthermore, the selection of the houses and the survey was done by the same person [2]. The explained procedure of the standard random by Schumann [2] was used as a basis. For this, a start point was defined, the study area was limited and an inspection was carried out. Details on the sample selection will not be discussed here. More detailed information on sample selection can be found in Schnell [1] and Schumann [2]. However the random selection of houses was also due to the closeness to the sinkhole and the related exposure of humans to the flushing water during the rainy season and odour in the dry season.

\section{The questionnaire}

The data collection was carried out by a questionnaire based on the extensive survey of Nayono $[3,4]$. The existing questionnaires included data for the whole desa ${ }^{2}$ Pucanganom and showed no limitation for particular dusun ${ }^{3}$. For that reason, a questionnaire was developed which dealt in detail with issues of water use and waste water sanitation in dusun B and C. This was based on the questionnaires Nayono [3,4]. The questionnaire included information on household size, daily water consumption, waste water quantities, material flow and their derivation or use, acceptance issues for the recycling of material flow as well as sanitation systems. Additional information about the sanitation situation provided the annually updated publication "Profil Desa". In total 80 households were interviewed and each survey amounted 20 to 25 minutes. The method of shared implementation of the interviews turned out to be purposeful and brought valuable results in order to avoid arrangements under each other and to ensure honesty in answering.

\section{Basis conditions and indicators}

Basis conditions were emerged with the data collection. First of all, three parent and fixed conditions were established which were accepted as given and unchangeable. These conditions were self- selected and include the climate, the three waste water streams (yellow, grey- and black water) and the area. Similarly, long-term and short-term variable conditions were considered such as cultural factors, the economic situation as well as the social conditions. From these conditions fifteen indicators were derived. Subsequently, the indicators were occupied with weighting factors. The determination of the weighting of the individual indicator with each other was performed with an Analytical Hierarchy Process (AHP). This method was originally developed by [5] and was used to determine the average weight of an indicator and thus represented a decision support [6]. Using a scale of one to five, the three concept proposals were evaluated whereby the five stands for well. Following the assessment of the individual treatment concepts based on the results a favourite was founded.

\section{Results and Discussion}

In total Pucanganom consists of 12 dusun. For the investigation the study area was limited on the parts A to C. The conducted tests, surveys and measurements were taken only in the areas $\mathrm{B}$ and $\mathrm{C}$ because of their proximity to the sinkhole. The pilot village lies in a rural area but densely populated and is one of the villages in the region which may have an increasing population. However 327 habitants per $\mathrm{km}^{2}$ living in the village $[3,4]$.

\section{Education and employment}

According to the previous survey conducted by Nayono [3,4], about $43 \%$ of the people who participated in the exercise attended primary school. However, only $1 \%$ of these possess a diploma certificate. Similarly, only $30 \%$ of the respondents had secondary school education, while about $19 \%$ of the respondents were presently in the high school. $5 \%$ of the people admitted that they have never attended school.

\section{Economic situation}

Because there is a lack of employment opportunities in other sectors, majority of the population constituting about $87 \%$ were employed in the agricultural sector [7]. Besides the heavy daily work in the field, there are only a few opportunities for generating additional income by engaging in other activities such as retail trading, construction and service sectors. More so, access to regional markets has become complicated due to the lack of good infrastructure, thus preventing additional sources of income. The cultivation of fruits and vegetables, which are done on a subsistence scale are mostly carried out to meet their own consumption, although a small amount is often produced for the local market.

\section{Infrastructure}

The dwelling houses in Pucanganom have an average size of 54 $\mathrm{m}^{2}$ and they are massive built with stone and brick. These randomly located on a site area of about $100 \mathrm{~m}^{2}$ to $120 \mathrm{~m}^{2}$ such that the dwelling houses of the neighbours are about 3 to 4 meters away from each other.

\section{Sanitation systems}

The simple bathroom consists of a concrete water tank and has a squat toilet. The toilet frequently has a ceramic holder or is often just a hole in the concrete floor. If the toilet is outside, it is the design of a cemplung ${ }^{4}$ and the washing facility is an open designed U-profile water tank. There is also a cistern $\left(9 \mathrm{~m}^{2}\right)$ located in the outdoor area of the most buildings which is built out of concrete. In the study area Pucanganom B and C the people are mostly use cemplungs, but some households have siphon toilets. Among the families who have a cemplung some complained about odour problems. Furthermore flies and mosquitoes are often a disturbing factor. The waste water from the cemplung and from the siphon toilet will be directed into a septic tank which is located in the garden. This tank is mostly inadequate constructed because of the self-financing. According to residents the septic tank is never full because the ground is out of such a good quality that all seeps directly into the ground. Partially the grey water from the washing facility in the outside area runs unobstructed in small open channels directly to the sinkhole by using the gradient.

${ }^{4}$ Pit latrine or Outhouse 
Citation: Fach S, Kaiser M, Fuchs S (2012) Development and Evaluation of Appropriate Concepts for Sewage Disposal and Treatment in a Rural Area, Central Java, Indonesia on the Example of the Village Pucanganom. Hydrol Current Res S1:002. doi:10.4172/2157-7587.S1-002

Page 3 of 5

\section{Organic waste}

Furthermore there are cows and goats in a shelter with a size of about $20 \mathrm{~m}^{2}$ on the property. Some families shared neighbouring land and operated common livestock breeding. The cow dung as a fertilizer is placed on the surrounding fields and the organic waste either is burned with plastic part or composted.

The remaining open areas are used for drying the manioc. In the study area Pucanganom more generations with the average of three to four people often live together in one household. Against the reuse of the process water the residents in the study area have shown positive reactions. The grey water is partly used for watering and for cleaning up the yard areas. According to the residents the water is too dirty.

In summary the resulting material flows are grey water ${ }^{5}$, black water ${ }^{6}$, rain water, organic waste and cow dung.

\section{Indicators and conditions}

The results above suggest the mentioned conditions and the following indicators can be derived (Table 1). The collecting data such as branches and also water availability show that for example the conditions on the economic situation are important for the concept. However the studies have shown that the region belongs to one of the poorest areas in Indonesia. Based on the condition, indicators like capital costs and energy consumption could be derived. In the following table 1 the main indicators developed by the authors based on the framework conditions were listed.

\section{Ideal indicators}

- Objective in this case is to find an adapted waste water treatment plant for Pucanganom. Adapted on the example of the pilot village Pucanganom means to consider people's needs, the cultural and social conditions described by the following ideal indicators. Investment costs should be as low as possible

- the system requires no electricity

- simple design, can be built out of material on site

\begin{tabular}{|c|l|l|}
\hline General conditions & Description & Indicators \\
\hline Fixed conditions & Tropical climate & Odour nuisance \\
\hline$\bullet \quad$ Climate & Black, grey, yellow water & $\begin{array}{l}\text { Disposal } \\
\text { Reuse }\end{array}$ \\
\hline$\bullet \quad$ Region & Rural area & Land requirements Slope \\
\hline Variable conditions & & \\
\hline$\bullet \quad$ Culture & Body cleansing, cleanliness & Water consumption Religious Acceptance Distance to sanitation \\
\hline$\bullet \quad$ Sociology & Poorest area in Indonesia & $\begin{array}{l}\text { Investment costs Operating costs Costs for users Material requirements } \\
\text { Energy consumptions }\end{array}$ \\
\hline
\end{tabular}

Table 1: Development of Indicators for the evaluation of the waste water treatment concepts based on fixed and variable conditions.

\begin{tabular}{|c|c|c|c|c|}
\hline & Sanitary System & Waste water stream & Treatment & Reuse \\
\hline \multirow{2}{*}{ A } & Composting Toilet/ Dry Toilet & Black water (Decentralized) & Co-Composting with bulking material (aerobic) & Soil conditioner \\
\hline & & Grey water (Decentralized) & Sand filtration (aerobic) & Irrigation/infiltration \\
\hline \multirow[t]{4}{*}{ B } & Siphon toilet/ Water toilet & Black water (Semi-decentralized) & Septic Tank - Pre-treatment (anaerobic); & \\
\hline & & & Sand filtration - liquid phase (aerobic) & Service water/infiltration \\
\hline & & & Sludge drying - solid phase (aerobic) & Soil conditioner \\
\hline & & Grey water (Decentralized) & Sand filtration (aerobic) & Service water/ infiltration \\
\hline \multirow[t]{5}{*}{ C } & Public bathroom and public toilet & Black water (Centralized) & Septic Tank - Pre-treatment (anaerobic); & \\
\hline & & & Sand filtration - liquid phase (aerobic) & Service water/ infiltration \\
\hline & & & Sludge drying - solid phase (aerobic) & Soil conditioner \\
\hline & & Grey water & Sand filtration (aerobic) & Service water/ infiltration \\
\hline & & (Centralized) & & \\
\hline
\end{tabular}

Table 2: Three Conceptions (A, B, C) of waste water treatment systems

${ }^{5}$ household wastewater without toilet discharge [8] ${ }^{6}$ toilet discharge (i.e. urine, faeces and flush water) [8] 
Citation: Fach S, Kaiser M, Fuchs S (2012) Development and Evaluation of Appropriate Concepts for Sewage Disposal and Treatment in a Rural Area, Central Java, Indonesia on the Example of the Village Pucanganom. Hydrol Current Res S1:002. doi:10.4172/2157-7587.S1-002

Page 4 of 5

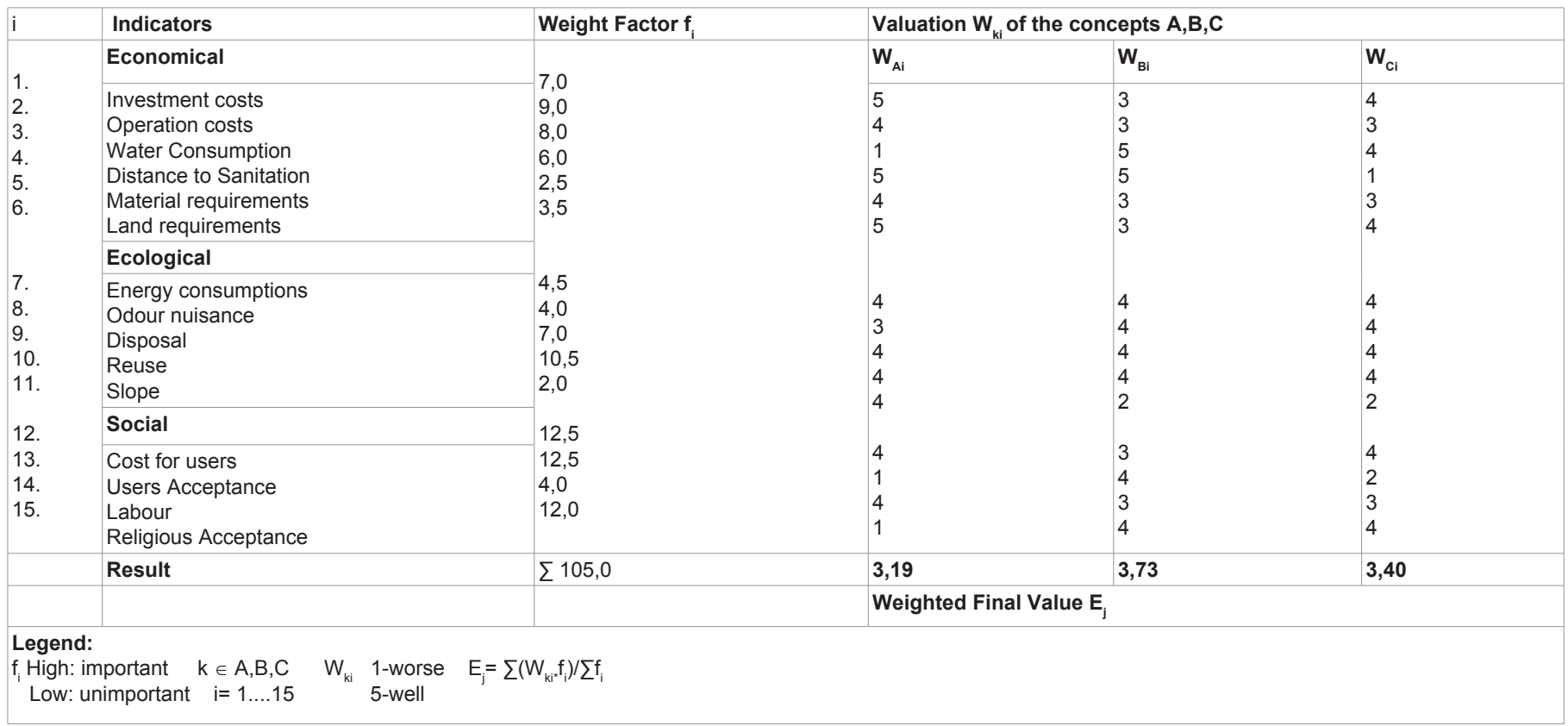

Table 3: Valuation of proposed concepts A, B, C,

- simple in dealing with investment

- low manpower required for operation and easy maintenance

- requires less space

- easy disposal due to health qualities

- system shall be easily expandable due to population growth, place requirement

- permanent functionality due to sustainability

- resistant on climate changes and robust

In compliance with the ideal indicators listed above the following concepts (Table 2) are created and are shown below. Those were related to the currents black water and grey water because rainwater, organic waste and cow dung are not separated in the concepts. Approaches for the treatment of the currents are listed in the final concept.

The concepts and indicators are combined and evaluated in table 3. By using the AHP (Analytical Hierarchy Process) method the indicators from table 1 are provided with a weighting factor $\mathrm{f}_{\mathrm{i}}$. This factor describes the importance of the selected indicators in relation to the indicators in table 1 . The concepts presented in table 2 are also evaluated in table 3 with the indicators shown in table $1\left(\mathrm{~W}_{\mathrm{Ai}}, \mathrm{W}_{\mathrm{Bi}}\right.$ ' $\mathrm{W}_{\mathrm{C})}$ ). The scale is from 1 to 5 . Whereby 5 is a well and 1 is a worse rating. As a final result the weighted values $\mathrm{E}_{j}$ were obtained.

Out of this method we get the concept B as the preferred concept with an $E_{j}$ value of 3, 73. Concept $A$ reached a value of 3, 19 and concept $\mathrm{C}$ has an $\mathrm{E}_{\mathrm{j}}$ value of 3,40. All three concepts are in the scale of 1 to 5 and reached a good midfield. Nevertheless concept A can be excluding because of the high use of water and concept $\mathrm{C}$ because of acceptance reasons.

\section{Conclusions}

By using the AHP method could be shown which indicators are more important than others. That for example could be demonstrated that socio- economic aspects such as the acceptance of the population played a major role in the selection of the concept. Despite the small differences between the weighted end values of the concepts $\mathrm{A}$ and $\mathrm{C}$, the concept $\mathrm{C}$ could be excluded because of low public acceptance. Similarly the high water consumption during the cleaning speaks against concept $\mathrm{A}$. The concept $\mathrm{B}$ recorded only a low score in the indicator gradient but is due to a low weighting of 2,0 negligibly.

Concept B proposes a (semi)- decentralized plant for the treatment of the black water due to the low population density and depending on the available space 4 to 5 households can be connected. Here the solid phase is treated anaerobic in a septic tank and the liquid phase is treated by using an aerobic sand filtration. Anaerobic waste water treatment has evolved due to the higher water temperature as a significant alternative to aerobic processes in tropical and subtropical countries [9]. For the separation of the liquids out of the sludge phase a septic tank with three consecutive flows- through settling chambers were used. The sludge is deposited by sedimentation in the first chamber and the discharge enters the additional chamber. Other anaerobic processes are used to reduce the organic material. Subsequent treatments of the pre- cleaned water as well as the treatment of sludge are the next steps after the preparation in a septic tank. For the further treatment of the sludge the material can be dried and recycled as a fertilizer and as an agricultural soil conditioner. The subsequent sand filtration treated the overhang liquid of the septic tank and can be discharged safely or used for irrigations in agriculture.

Grey water is cleaned in a decentralized sand filtration directly at the house and can be used as process water for cleaning purposes of court. Rainwater can be also treated by a sand filtration to reduce the turbidity. Disinfection is not necessary because basically water is boiled before using for drink water purposes. Organic waste is currently burned together with plastic waste. For use as a fertilizer the organic waste can be treated anaerobic in the septic tank together with the black water or even treated aerobic as compost. Cow manure is already used as fertilizer and is also available in the concept presented here. 
Citation: Fach S, Kaiser M, Fuchs S (2012) Development and Evaluation of Appropriate Concepts for Sewage Disposal and Treatment in a Rural Area, Central Java, Indonesia on the Example of the Village Pucanganom. Hydrol Current Res S1:002. doi:10.4172/2157-7587.S1-002

Page 5 of 5

The subsequent work will deal with the detailed planning by using the data collection above with the results of water use or availability of land for the implementation of the concept. So an implementation in a pilot scale can be performed. An intervention into an existing system requires a detailed capacity development among the population.

\section{Acknowledgement}

We would like to thank Federal Ministry of Education and Research for financial support.

\section{References}

1. Schnell R, Hill P, Bernhard Esser, Elke (1998) Methoden der empirischen Sozialforschung. 6, unverand. München [u.a.]: Oldenbourg.

2. Schumann S (2006) Reprasentative Umfrage: praxisorientierte Einführung in empirische Methoden // Repräsentative Umfrage. Praxisorientierte Einführung in empirische Methoden und statistische Analyseverfahren. 4., überarb. und erw. München [u.a.]: Oldenbourg.

3. Nayono T (2011) Output Survey Pucanganom in cooperation with the Institute for Technology Assessment and Systems Analyses (ITAS).

4. Profil Desa: statement of Nayono, T. in a conversation in July 2011, Yogyakarta.

5. Saaty T (1980) The analytic hierarchy process: planning, priority setting, resource allocation; McGraw-Hill International Book Co.
6. Bernasconi M, Choirat C, Seri R (2010) The Analytic Hierarchy Process and the Theory of Measurement. Management Science 56: 699-711.

7. Hossu M (2009) Zwischen Wassermangel, Siedlungshygiene und Armut Lokale Bewältigungsstrategien in Gunung Kidul, Indonesien. Diplomarbeit. Betreut von Prof. Dr. U. Scholz. Gießen. Justus-Liebig-Universität Gießen, Geographisches Institut.

8. DWA (2008) DWA-Themen Neuartige Sanitärsysteme DWA, Hennef.

9. Dichtl N, Bischofsberger W, Rosenwinkel KH (2004) Anaerobtechnik Handbuch der anaeroben Behandlung von Abwasser und Schlamm. 2., vollst. überarb. Berlin: Springer.

10. Bahgat M, Dewedar A, Zayed A 1999) Sand-filters used for waste water treatment: buildup and distribution of microorganisms. Water Research 33 1949-1955.

11. Haryono E, Day M (2004) Landform differentiation within the Gunung Kidul Kegelkarst, Java, Indonesia. Journal of Cave and Karst Studies 66: 62-69.

12. Sutardi (2004) Indonesia's Water Resources Policy Reform Process (\#175).

13. UNEP (2002) Environmental sound technologies in waste water treatment for the implementation of the UNEP Global programme of action (GPA) Guidance on municipal waste water.

14. WHO (1992) A Guide to the Development of on-Site Sanitation, WHO.

This article was originally published in a special issue, Water Resources Research handled by Editor(s). Dr. Maria Papadaki, University of Leeds, United Kingdom 